\title{
INTRAMUSCULAR SUCCINYLCHOLINE FOR ENDOTRACHEAL INTUBATION IN INFANTS AND CHILDREN. II
}

\author{
J. Beldavs, M.D.*
}

THE AUTHOR has previously reported the use of intramuscular succinylcholine for the production of relaxation for endotracheal intubation in infants and children. ${ }^{1}$ The purpose of this communication is to report further satisfactory experience with this method.

During a period of three years, succinylcholine chloride was used intramuscularly to provide a complete flaccid paralysis for endotracheal intubation in over 400 patients varying in age from a few hours to 10 yearsl Adequate relaxation was achieved in all patients where the following dosage scale was used: new-born to 3 years; $1.5 \mathrm{mg}$. per pound of body weight; 4 years and older, $2 \mathrm{mg}$. per pound of body weight.

Succinylcholine was used in the form of a 10 per cent solution of Anectine (Burroughs Wellcome \& Co. Ltd.), i.e., a solution containing $100 \mathrm{mg}$. of succinylcholine per cubic centimetre. ${ }^{1}$

The period of time necessary to achieve a complete flaccid paralysis or relaxation varies between less than one minute to three minutes. Obviously, even if the same amount of solution were absorbed in all age groups in a given period of time, the same amount of drug absorbed would create a higher level of succinylcholine in the blood in the smaller child, because of the smaller blood volume. In infants under one year of age it is found that a complete paralysis and readiness for intubation followed injection in a period of one minute or less. In the age group 1 to 5 years, complete relaxation followed within a period of two minutes or less after the injection. In children 6 years and older the time was sometimes longer than two minutes, but never exceeded three minutes from the time of injection.

The intramuscular injection of succinylcholine did not cause a slowing of the heart rate as did an intravenous injection in infants and children, ${ }^{2}$ but, on the contrary, the intramuscular injection of the above-mentioned doses of succinylcholine was usually followed by an increase in the heart rate. Johnstone $e^{3}$ states that intravenous administration of succinylcholine is of ten followed by changes in the cardiovascular system similar to those caused by acetylcholine. These include the muscarinic effect, which is characterized by slowing of the pulse rate and fall in blood pressure. This reaction is followed in 1 to 2 minutes after a rapid intravenous injection by a nicotinic stimulation, which increases the pulse rate and blood pressure. Our series shows that if succinylcholine is given intramuscularly in the doses that we have used, the nicotinic effect prevails over the muscarinic and there is no slowing of the heart rate. The relatively slow absorption of the drug when it is given intramuscularly may abolish the muscarinic effect.

*Hôpital Maisonneuve, Montreal, Quebec.

Can. Anaes. Soc. J., vol. 9, no. 4, July, 1962 
Little $^{4}$ uses succinylcholine infusion for mitral commissurotomy in very lightly anaesthetized cardiac patients. He finds no deleterious effects of succinylcholine on the cardiovascular system, I feel that if a child is a bad risk cardiac patient, the intramuscular succinylcholine induction is the method of choice, because hypoxia caused by straining and laryngospasm can be prevented. Nevertheless, there may be a slowing of the heart rate during the intubation or inflation of a very lightly anaesthetized patient due to parasympathetic stimulation. Premedication with a parasympathetic blocking agent is therefore desirable. Atropine was found to be quite satisfactory. Junkin ${ }^{5}$,preferred atropine to hyoscine in children because with hyoscine he observed a higher incidence of undesirable cardiovascular reactions than with atropine. Walton ${ }^{6}$ claims that the incidence of bradycardia in children undergoing surgery of the eye or oropharynx is increased by_ inadequate atropinization, and ether does nor have a protective effect against the bradycardia. Burstein ${ }^{7,8}$ attributes cardiac arrhythmias to insufficient depth of anaesthesia, prolonged laryngoscopy, respiratory obstruction, and irritation by the tube. He suggests that most of the arrhythmias are transient and of no grave importance. Johnstone ${ }^{3}$ attributes the appearance of extrasystoles during intubation of very lightly anaesthetized patients to hypoxia, and extrasystoles occasionally appeared when the patients were allowed to remain apnoeic for periods of forty seconds or more. In his series there were brisk increases in sinus rates of all patients during the insertion of the endotracheal tube. He used light thiopentone anaesthesia (200-250 mg. in adults) and succinylcholine intravenously. This generally is in agreement with our findings, although in a few cases in children premedicated with scopolamine there was a slowing of pulse rate and extrasystoles during insertion of the tube which I could not with certainty attribute to hypoxia. Davies ${ }^{9}$ and Dales ${ }^{10}$ suggest that the endotracheal tube in an inadequately anaesthetized patient may cause bronchial spasm. This did not occur in our patients, although they were very lightly anaesthetized with nitrous oxide and oxygen $3: 1$ at the time of intubation. Davies ${ }^{9}$ also stresses the importance of loss of potency of the succinylcholine solution if it is stored at room temperature. For that reason the succinylcholine used in our cases was stored in the refrigerator.

A delayed effect of the relaxant was not observed with the standard dosages and all patients were breathing sufficiently to permit extubation within 25 minutes or less. Stead, ${ }^{11}$ using succinylcholine intravenously in over 300 neonates, did not see a prolonged response in spite of the infants' low normal pseudocholinesterase level. He found in a series of 20 new-born infants that a neonate requires at least twice the dosage to produce an effect comparable with that in an adult. McAlpine and Bowering ${ }^{12}$ report 2 cases in a series of 3,262 infants and children induced with succinylcholine intravenously, where a delayed effect lasting $1 \frac{1}{2}$ hours occurred in a 3 -year-old girl, while her brother was apnoeic for 20 minutes; but both children had a poisoning with an anticholinesterase insecticide prior to operation, caused by fumigation of a basement. ${ }^{13}$

Though some may argue that the incidence of infant morbidity may be increased by the occasional trauma of intubation, Percheson and Carroll ${ }^{14}$ feel that the safety and control established by the tube is a major factor in lowering 
surgical mortality, because intubation makes anaesthesia safer, more physiological, more controllable, more predictable, and more reversible. Endotracheal anaesthesia for tonsillectomies was advocated by Slater and Stephen ${ }^{15}$ in 1951, and by Pender and Hallberg ${ }^{16}$ in 1953. McAlpine and Bowering ${ }^{12}$ feel that the advantages of endotracheal intubation for tonsillectomies are so apparent that reluctance to intubate can only be caused by inadequate equipment or poor technique.

I think that the objections that persist in some hospitals to the intubation of infants for the correction of oesophageal atresia or tracheo-oesophageal fistula because of the fear of laryngeal oedema ${ }^{17}$ would not have originated if the intubation were made easy by using a relaxant prior to the intubation. Laryngeal oedema may follow intubation and it is more common in infants, where no relaxant is given prior to intubation, than in older children or adults. ${ }^{18}$ In most of the reported cases of severe oedema it appeared that induction and intubation were lengthy and difficult. ${ }^{19,20,21}$

Stead ${ }^{11}$ considers it dangerous to inject a relaxant drug in new-born infants without first intubating ard obtaining full respiratory control. We did not find any difficulty in our series in inflating new-born on very young infants by mask, whether they were fully paralysed after intramuscular succinylcholine or apnoeic after delivery, and it was possible to perform the intubation with extreme gentleness. I had great difficulty in intubating a baby after a Caesarean section, where the baby was dead for some time before the operation and had a rigor mortis. It was possible to open the mouth and insert a laryngoscope, but the stiffness of the small laryngeal muscles did not permit lifting the epiglottis and exposing the inlet of the larynx. This corresponds with the statement of Davenport ${ }^{22}$ that in children it is often difficult to lift the epiglottis, as he prefers to intubate newly born infants in the conscious state, where there isconsiderable resistance of the muscles, which tend to close the glottis. This difficulty would be abolished by use of a relaxant. Davenport states that in infants it is difficult to keep the natural airway patent during the period of partial paralysis until the drug is fully effective, and therefore he prefers rapidly acting relaxants by the intravenous route. At the beginning of our series we had the same difficulty, which arises if the anaesthetist tries to start controlled respiration by mask immediately after the injection of the relaxant. This causes resistance and breathholding in the not yet paralysed baby. ${ }^{1}$ For that reason the mask should not be put on the face of the baby immediately after the injection if the baby is not asleep, but the anaesthetic mixture should be flown freely down to the face and the mask applied, and assisted but not controlled respiration started when the spontaneous respirations become shallow. If the infant was asleep prior to the injection of the relaxant, again it may not be deep enough for controlled respiration and attempts at controlled respiration may cause a breathholding or laryngospasm. Here again the respiration must be gently assisted when it becomes shallow, and controlled when apnoea ensues. The inflation should always be done very gently as the stomach is often filled up with gas by beginners with this method. The stomach can be easily deflated in a relaxed infant by inserting a catheter down the oesophagus. 
Kennedy ${ }^{23}$ uses succinylcholine intramuscularly during operations, but intubates infants conscious or after induction with open drop ether.

The contraindications for using a relaxant prior to intubation in infants and children are similar to those in adults and can be detected prior to the induction of anaesthesia. The contraindications are: partial obstruction of the respiratory tract, infective swellings around the glottis and in the pharynx, recession of the chin or marked protrusion of the maxilla (Pierre-Robin syndrome ${ }^{22}$ ), full stomach, and haemorrhage in the upper airway. ${ }^{22}$ In a state of shock the peripheral circulation may not be satisfactory and all injections should be given intravenously instead of intramuscularly. Infants with cleft lip and palate can be intubated easily with intramuscular relaxant when the cleft in the pallate is packed by a sponge to provide a support for the laryngoscope..$^{22,24}$

I consider that the method of giving succinylcholine intramuscularly prior to intubation in infants and children renders the induction smooth and of short duration. The importance of this is emphasized in all methods of anaesthesia.

\section{SLMMARY}

In a period of three years over 400 children and infants of the age of a few hours to 10 years were intubated after being given succinylcholine chloride in a 10 per cent solution intramuscularly. The smaller the child the faster the full relaxation took place after the injection, i.e., in a period of time that varies between 1 minute or less to 3 minutes. The dosage of the succinglcholine was: $1 \frac{1}{2} \mathrm{mg}$. per pound of body weight in patients the age of 3 years and younger and $2 \mathrm{mg}$. per pound in patients 4 years and older.

The advantages of this method were:

1. Smooth and short induction of anaesthesia.

2. It was considered good for bad risk cardiac patients as any straining and crying could be avoided.

The main objections were:

1. That an infant or child may be difficult or impossible to intubate even if a relaxant was given, and therefore it was considered unsafe to give a relaxant to an infant or child prior to intubation. The author of this article did not find any difficulties in intubation in his series, but considers that a recession of the chin or protrusion of maxilla (Pierre-Robin syndrome), which can be detected prior to the induction of anaesthesia, is a contraindication for giving a relaxant prior to intubation. Cleft palate and lip was not considered a contraindication for the method.

2. That it is difficult to keep the natural airway patent during the period of partial paralysis until the drug is fully effective. We think that this difficulty may be caused by breathholding and straining of the patien't if controlled respiration, instead of assisted, is attempted before the patient is fully relaxed.

3. That injection of succinylcholine in an infant or child may cause a marked bradycardia. The injection of the above-mentioned dosage of succinvlcholine i.m. does not seem to cause a slowing of the heart.

4. That the pulmonary inflation or intubation of a very lightly anaesthetized 
patient may cause a slowing of the heart and sinus arrhythmias due to parasympathetic stimulation. To avoid this I consider that the use of atropine in premedication is essential.

\section{RÉSUMÉ}

Pendant une période de trois ans plus de 400 enfants et bébés agés de quelques heures à 10 ans ont été intubés après qu'on leur eut donné du chlorure de succinylcholine intramusculaire.

Plus l'enfant est petit, plus vite se produira le relâchement complet après l'injection, dans une période de temps qui varie de moins d'une minute à trois minutes.

Le dosage de chlorure de succinylcholine était $1 \frac{1}{2} \mathrm{mg}$. par livre du poids du malade à l'âge de 3 ans ou plus jeune et $2 \mathrm{mg}$. par livre à l'âge de 4 ans et plus âgé.

Les avantages de cette méthode étaient:

1. Facile et court commencement de l'anesthésie.

2. C'était considéré comme étant une bonne chose pour un malade cardiaque en mauvais état afin d'éviter les cris et les efforts du malade.

Les principales objections staient:

1. Qu'un enfant ou un bébé puisse être difficile ou impossible à intuber même après qu'un paralysant musculaire ait été donné, et c'est pourquoi il était considéré comme dangereux d'injecter un paralysant avant l'intubation. Je n'ai rencontré aucune difficulté d'intubation dans ma série. Un retrait du menton ou une projection de la mâchoire supérieure (Syndrome de Pierre-Robin), qui peut être détecté avant le commencement de l'anesthésie, est une contre-indication pour donner un paralysant avant l'intubation. Lne fissure du palais ou un bec de lièvre n'était pas considéré comme une contre-indication pour cette méthode.

2. Qu'il est difficile de garder le passage de l'air naturel pendant la période de paralysie partielle jusqu'à ce que l'effet du médicament soit complet. Je pense que cette difficulté peut être causée par la retention de la respiration et les efforts du malade si la respiration contrôlée est tentée avant que le malade soit complètement paralysé à la place de la respiration assistée.

3. Que l'injection de chlorure de succinylcholine à en enfant ou bébé peut causer une bradycardie marquée. L'injection du chlorure de succinylcholine i.m. d'après les doses ci-dessus ne semble pas causer un ralentissement du coeur.

4. Que l'insufflation des poumons et l'intubation d'un sujet qui est très légèrement anesthésié peut causer un ralentissement du coeur ou une arythmie du sinus due à la stimulation parasympathique. Pour éviter ceci, je considère que l'atropine est essentielle dans la prémédication.

Cette méthode comme d'autres où la respiration doit être arrêtée avant l'intubation exige la surveillance d'un anesthésiste expérimenté.

\section{REFERENCES}

1. Beldavs, J. Intramuscular Succinylcholine for Endotracheal Intubation in Infants and Children. Canad. Anaesth. Soc. J. 6(2): 141 (1959).

2. Leigh, M. D. et al. Bradycardia Following Intravenous Administration of Succinylcholine Chloride to Infants and Children. Anesthesiology 18: 698 (1957).

3. Johnstone, M. Relaxants and the Human Cardio-vascular System. Anaesthesia 10(2): 122 (1955). 
4. Little, D. M. \& Sutton, G. C. Succinylcholine-Nitrous Oxide Anaesthesia for Mitral Commissurotomy. Canad. Anaesth. Soc. J. 2(2): 156 (1958).

5. Junkin, C. I. Preoperative Medication for Children. Canad. Anquesth. Soc. J. 3(1): 208 (1956).

6. Walton, F. A. Reflex Bradycardia in Ophthalmic and Oropharyngeal Surgery. Canad. Anaesth.'Soc. J. 4(4): 414 (1957).

7. Burstein, C. L.; Lopinto, F. J.; \& Newman, W. Electrocardiographic Studies during Endotracheal Intubation. Anesthesiology 11: 224 (1950).

8. Burstein, C. L.; Woloshin, G.; \& Newman, W. Electrocardiographic Studies during Endotracheal Intubation 2. Anaesthesiology 11: 299 (1950).

9. Davies, J. I. Untoward Reactions to Succinylcholine. Canad. Anaesth. Soc. J. $B(1)$ : 11 (1956).

10. Dales, J. W. Bronchospasm: A Case Report. Canad. Anaesth. Soc. J. 5(2): 209 (1958).

11. Stead, A. L. The Response of the New-born Infant to Muscle Relaxants. Brit. J. Anaesth. Q7 (3): 124 (1955).

12. Mcalpine, F.D. \& Bowering, W. M. Anaesthesia for Tonsillectomy and Adenoidectomy in Children. Canad Anaesth. Soc. J 5(1):61 (1958).

13. Wielhorski, A. W.; Dubeau, M.; \& Riopel, P. Plasma Cholinesterase Studies in Some Pathological Conditions in Man. Canad. Anaesth Soc. J. 8 (1): 31 (1956).

14. Percheson, P. B. \& Carroll, J. J. Difficulties in Paediatric Anaesthesia. Canad. Anaesth. Soc. J. 5 (2): 115 (1958).

15. Slater, H. M. \& Stephen, C. R. Anaesthesia for Tonsillectomy and Adenoidectomy. Canad. M.A.J. 64: 22 (1951).

16. Pender, J. W. \& Hallberg, O. E. Endotracheal Anaesthesia for Tonsillectomy and Adenoidectomy in Children. J.A M.A. 153: 1073 (1953).

17. Swenson, O. The Diagnosis and Treatment of the Esophagus and Tracheoesophageal Fistula. Surg., Gynec. \& Obst. 76: 672 (1943).

18 Crispeld, L. S. \& Hampton, L. J. Laryngeal Edema Complicating Endotracheal Anaesthesia. Connecticut M.J. 14: 98 (1950).

19. Shaw, W. M. Edema of the Larynx a Rare Complication of Eindotracheal Anaesthesia. Anesthesiology $7: 416$ (1946)

20. Sмiтн, R. M. Prevention of Trachertis in Children Following Endotracheal Anaesthesia. Anesth. \& Analg. 82: 102 (1953).

21. Carruthers, H. C. \& Graves, H. B. The Complications of Endotracheal Anaesthesia. Canad. Anaes. Soc..J. $3(3): 244(1956)$.

22. Davenport, T. H. \& Rosales, K. j Endotracheal Intubation of Fnfants and Children. Canad. Anaesth. Soc. J. 6 (1). 65 (1959).

23. Kennedy, L. R. \& Stoelting, V. K. Anaesthesia for Surgical Repair of Oesophageal Atresia and Tracheo-Oesophageal Fistula. Canad. Anaesth. Soc. J. 5 (2): 132 (1958).

24 Kilduff, J. C.; Wyant, M. G.; \& Dale, H. R. Anaesthesia for Repair of Cleft Lip and Palate in Infants using Moderate Hypothermia. Canad Anaesth Soc. J. 3 (2): 102 (1956). 